\title{
Szülésznók tapasztalatai a szülés során létrejövő segítő kapcsolatról: interpretatív fenomenológiai analízis
}

\author{
SZÉKELY ZSÓFIA ${ }^{1 *}$ - CSABAI MÁRTA² \\ ${ }^{1}$ Károli Gáspár Református Egyetem, Tanárképző Központ, Budapest \\ ${ }^{2}$ Szegedi Tudományegyetem, Pszichológiai Intézet, Szeged
}

(Beérkezett: 2017. november 8.; elfogadva: 2018. március 19.)

\begin{abstract}
Elméleti háttér: A vajúdást/szülést vizsgáló tudományos kutatások többsége biomedikális szemléletben fogan, eredményeik ezt a paradigmát tükrözik vissza. Az utóbbi időben nyernek teret holisztikus kérdésfeltevéssel és módszerekkel dolgozó kutatások, amelyekhez kvalitatív vizsgálatunkkal csatlakozunk. A kórházban történő vajúdás/szülés többnyire medikalizált, elgépiesedett környezetben, elszemélytelenedett ellátás keretein belül zajlik. Ez a folyamat az orvosi technológia fejlődésének mellékterméke, amely egyaránt negatívan érinti a szülő nőt és terheket ró a szakemberre is. A szülés körüli segítők számára jelentős kihívásokat jelenthet a humanizált, személyre szabott ellátás megvalósítása, amelyet gyakran tovább súlyosbít a női szakemberek nehezített hatalmi-függőségi pozíciója. Cél: A szülés körül segítő női szakemberek kapcsolati élményeinek idiografikus feltárása. Hogyan használhatóak magyarázó elvként a gyógyító kapcsolatról alkotott pszichodinamikus elméletek a szülés körüli segítéssel kapcsolatban? Hogyan jelennek meg nemre specifikus szempontok a vajúdás / szülés körüli segítés tematikájában? Módszer: Kvalitatív kutatás interpretatív fenomenológiai analízissel (IPA). A vizsgálati helyzet felépítése: félig strukturált mélyinterjú, tematikus képekkel kiegészítve. Az interjúalanyoktól egy szabadon választott szüléstörténetet kértünk, és további kérdéseket is feltettünk a munkájukkal kapcsolatban. A válaszokat IPA módszerrel elemeztük. Vizsgálatban résztvevők: 5 kórházi szülésznő, 5 bába, 4 dúla (14 fö). Jelen tanulmányunkban 4 kórházi szülésznővel készült interjút elemzünk. Eredmények: A szövegek elemzése során meghatározott témák: interjúalanyaink megfogalmazták, hogy a vajúdás/szülés melletti segító munkában elengedhetetlen a személyes és szakmai önismeret; gyakran tanulnak a vajúdó nőktől; munkájuk anyai gondoskodással, érzelmi és fizikai támasz nyújtásával jár együtt; gyakoriak a konfliktusok a más szemléletú kollégákkal. A témákat fötémák szerint csoportosítottuk: a szakmai identitás fejlődése és a vajúdóval való kapcsolat megélése az élmények lényegi meghatározója. Következtetések: A szakmai identitás és a vajúdóval való kapcsolat kölcsönösen determinált, egyfajta „közös út”, amelyen a segítő kapcsolatban résztvevők együtt haladnak. Eredményeink alapján feltételezhető, hogy a medikalizált, intézményesített körülmények megnehezítik a személyre szabott, érzelmi támogatást tartalmazó, magas szakmai színvonalú segítségnyújtást. Interjúalanyaink egyéni megoldásokat keresnek a polarizált helyzetból adódó konfliktusaikra. Ezek helyett szakmailag megalapozott iránymutatásra és támogatásra lenne szükség.
\end{abstract}

\footnotetext{
* Levelező szerző: Székely Zsófia, Károli Gáspár Református Egyetem, Tanárképző Központ, 1147 Budapest, Dózsa György út 25. E-mail: zsofko@gmail.com
} 
Kulcsszavak: interpretatív fenomenológiai analízis, vajúdás, szülés, segítő kapcsolat, medikalizáció, humanizált szülészeti ellátás, szakmai identitás fejlődése.

\section{Bevezetés}

A várandósság/vajúdás/szülés elsősorban a medikális szemlélet mentén, az orvos és beteg (vagy egészségügyi dolgozó és páciens) fogalmi rendszerében és viszonyaiban interpretálódik. Az orvosi technológia fejlődése, minden eredménye mellett, a kórházi vajúdás/szülés elgépiesedését, elszemélytelenedését hozta magával (Soltész, Rigó, \& Pápay, 2015); ugyanakkor általános jellemzője, hogy kiszámíthatatlan, milyen ellátásban részesül a vajúdó-szülő nő (Varga, Andrek, \& Herczog, 2011). Mindemellett tudományos és köznapi értelemben sem tartjuk betegségnek az élettani vajúdást és szülést; és nem tartjuk betegnek vagy páciensnek a várandós/vajúdó/szülő nőt (Pápay \& Rigó, 2015). A tudományos kutatások elsöprő többsége a medikális szemlélet mentén szerveződik, és eredményeik is ezt a paradigmát tükrözik vissza. Az utóbbi időben nyernek teret a holisztikus szemléletú kérdésfeltevéssel és módszerekkel dolgozó kutatások (Davis-Floyd, 1992; Kisdi, 2015; Kitzinger, 2008). A vizsgálódások témájukat tekintve általában a szülés és születés élményét, a folyamat medikális és bio-pszichoszociális összetevőit taglalják (Pápay \& Rigó, 2015; Varga és mtsai, 2011). Újabb keletú és kevesebbet kutatott téma a szülés körüli segítók munkájának fókuszba állítása (Hunter, 2001; Hunter, Berg, Lundgren, Ólafsdottir, \& Kirkham, 2008; Kisdi, 2015; Kitzinger, 2008). A medikalizált szülészeti gyakorlat az utóbbi harminc évben humanizálódik, de ez a változás még nem vált rendszerszinten általánossá. A holisztikus szemlélet felé hajló, humanizált szülészeti ellátást gyakorló orvosok és szülésznők tapasztalataikon alapuló tudásukat, kutatási eredményeiket viszonylag ritkán publikálják (Novák, 2015).

A vajúdás/szülés a nő számára komplex és egyedi élmény, amely szoros összefüggésben van a ,jó minőségü" szüléssel, és az újszülött pozitív élményével (Larkin, Begley, \& Devane, 2009; Varga, 2015). Bizonyos kutatások kiemelik, hogy a pozitív szülésélmény létrejötte jelentős összefüggést mutat a bába személyéhez kötődő bizalom kialakulásával (Larsson, Saltvedt, Edman, Wiklund, \& Andolf, 2011; Varga, 2015). Az érzelmi-fizikai támogatás az élettani vajúdás/szülés szakszerú kísérésének alapvető összetevője (Lundgren \& Dahlberg, 2002; Lundgren, Karlsdottir, \& Bondas, 2009; Romano \& Lothian, 2008). A megfelelő társas támogatás pedig jelentős szülészeti előnyöket is eredményezhet, így például a vajúdás/szülés haladásához elengedhetetlen centrális oxitocin rendszer főként megfelelő társas környezetben tud aktiválódni (Héjja-Nagy, 2014; Soltész és mtsai, 2015; Taylor és mtsai, 2000; Uvnäs-Moberg \& Peterson, 2004; Varga, 2009). A vajúdás során természetes módon létrejövő módosult tudatállapot hatására a testérzé- 
kelés és az érzelmek felerősödnek, nagy jelentőséget kapnak, ebből következően a jelenlevőkkel megélt együttes élmény is. Ez a jelenség komoly hatással van a segító és a vajúdó közötti kommunikációra is; a vajúdó egyrészt szuggesztibilisebbé válik, másrészt kiszolgáltatottabbá is: a máskor jól múködő énvédelem vajúdás közben gyakorlatilag megszúnik (Héjja-Nagy, 2014; Kitzinger, 2008; Varga \& Suhai-Hodász, 2010).

A medikális környezet, a hierarchikus kórházi protokoll szigorú szabályai többnyire nem teszik lehetóvé, vagy nagyon megnehezítik az intimitás megteremtését a vajúdás helyszínén. Ez nemcsak a vajúdók, hanem a szülés körüli segítők számára is jelentős stresszforrás, hiszen ebben a helyzetben érző, érzékelő segítőként vannak megszólítva, ugyanakkor a szabályok legalább annyira korlátozzák a lehetóségeiket, mint a vajúdókét. A segító foglalkozásúak a megnövekedett stresszre legtöbbször érzelmi távolságtartással reagálnak: kizárólag a feladatokra koncentrálnak, eltűnik az együttérzés, empátia, majd a páciens tárgyiasítása jelenik meg (Hunter, 2001; Kovács, 2006). A kiégés jelenségének vizsgálata kiemelt területe a segító kapcsolatok kutatásának (Fülöp, 2013; Pikó, 2005). A nővéri munka érzelmi aspektusait számos kutatás tárgyalja, de az intézményes keretek között dolgozó bábák és szülésznők érzelmi munkájának vizsgálata legtöbbször kívül marad a kutatók érdeklődési körén, miközben az intézményen kívüli szüléseknél dolgozó bábák munkáját elemző tanulmányokban explicit módon jelenik meg a megélt érzelmek kifejezésének és szabályozásának jelentósége (Hunter, 2001). Az intézményes kereteken kívül múködő bábák praxisában többnyire megvalósul az érzelmi ráhangolódás, a személyre szabott gondoskodáson keresztül: ezt nevezik rezonancián alapuló orvoslásnak (Resonance Based Medicine, RBM; Lipták, 2017; Novák, 2015). A vajúdás/szülés során létrejövő segítő kapcsolat minősége kiemelt jelentőségú a magas szakmai színvonalú ellátás tekintetében, ugyanakkor éles, látszólag összebékíthetetlen ellentmondások figyelhetók meg mind a gyakorlat, mind a tudományos kutatások diskurzusainak színterein. A segító munka más-más attribútumokkal írható le a szülész-orvos, a kórházi szülésznő, az intézeten kívül dolgozó bába és a dúla esetében. Kevés tudományos figyelem irányul kifejezetten a nők közötti segítség dinamikájára, a segítók szempontjainak megvilágítására. Kutatásunk a női segítők élményének feltárásával és kvalitatív elemzésével kíván hozzájárulni a téma tudományos diskurzusához.

\section{Célkitúzés}

Célunk a szülés körül segító nők kapcsolati élményeinek feltárása volt. Kutatási kérdéseink a következők voltak: Hogyan élik meg a szülés körüli segítők a segítő kapcsolatot, és hogyan értelmezik a tapasztalataikat? Ezen tapasztalatok kutatói megértéséhez hogyan használhatóak magyarázó elv- 
ként a pszichoterápiás kapcsolatról alkotott pszichodinamikus elméletek a szülés körüli segítéssel kapcsolatban? Hogyan jelennek meg a nemre specifikus (gendered) szempontok a vajúdás / szülés körüli segítés tematikájában? Kvalitatív kutatásunkban a vajúdás/szülés során létrejövő segítő kapcsolatok közül a szülésznők, bábák és dúlák élményeit vizsgáljuk. A kutatáshoz szükséges etikai engedélyt az Egyesített Pszichológiai Kutatásetikai Bizottság adta ki (az etikai engedély száma: 43/2015).

Az alábbiakban először bemutatjuk a teljes kutatás felépítését, majd négy interjú kvalitatív elemzése kapcsán a segítő kapcsolat és a szakmai identitás kialakulásának mozzanataira fókuszálunk.

\section{Módszer}

A szülés körüli segítók kapcsolati élményeinek vizsgálatához olyan módszert kerestünk, amely alkalmas arra, hogy az általunk kutatott témát egyediségében és mélységeiben is feltárjuk. Az interpretatív fenomenológiai analízis - IPA - értelmező és hermeneutikai kvalitatív módszer, amelyet többnyire az egészségpszichológiai kutatások alkalmaznak (Rácz, Kassai, \& Pintér, 2016; Smith, Flowers, \& Larkin, 2009). Sajátossága a többszintú, mind az interjúalany, mind a kutató értelmezéseit alkalmazó adatfeldolgozás. Az IPA interjú lehetôvé teszi, hogy a személyek saját szempontjaik szerint beszéljenek tapasztalataikról, illetve értelmezzék azokat. Az egyéni tapasztalatok idiográfiás, részletes elemzését, és az eredmények árnyalt értelmezését a kutatók szervező és értelmező szerepe segíti elő (Rácz és mtsai, 2016; Smith és mtsai, 2009). Az interpretatív fenomenológiai analízis során az adathalmaz puszta leírásán túl interpretáljuk az eredményeket, azaz kettős értelmezéssel élünk: a személyek saját történeteikkel kapcsolatos értelmezéseit elemezzük, továbbá lehetóség van pszichodinamikus konstruktumokat is beemelni az értelmezési folyamatba. Magyarországon viszonylag új keletú az IPA alkalmazása a kvalitatív vizsgálódások körében (Rácz, Kassai, \& Pintér, 2015), így kutatásunk hozzájárul e módszer tapasztalati anyagának gazdagításához.

A szakirodalom által javasolt kreatív kutatómunka irányelvével összhangban (Rácz és mtsai, 2015, 2016), előzetes folyamat során kiválasztottunk négy, vajúdást ábrázoló képet ${ }^{1}$ és meghatároztuk az interjút segítő témákat és kérdéseket. A tematikus képek, a félig strukturált mélyinterjú, és a kiegészítő kérdések kombinációja biztosítja az adattriangulációt (Szokolszky, 2004). A megbízhatóság további növelése érdekében a kutatói

\footnotetext{
1 Ezek a képek valós vajúdások fotói különböző forrásokból, de csak a kutatásban való közvetlen felhasználásra kaptunk engedélyt, publikálásra nem, ezért itt nem közöljük.
} 
értelmezéseket külön-külön, és közösen is elvégeztük, továbbá több résztvevővel is egyeztettünk az eredményeket illetően, a vizsgálat lefolytatása után (személyi trianguláció és member-checking, Szokolszky, 2004). A vizsgálati helyzet a feltárulkozás tere is egyben: igyekeztünk olyan körülményeket teremteni, ahol őszinte és mély beszélgetés alakulhat ki, és ahol megérthetjük az interjúalanyok történetét és élményeit; ahol egyenrangú partnernek tekintjük a személyeket, így közösen, rugalmasan alakítjuk az interjúhelyzetet és lehetőséget biztosítunk sajátos, női realitásuk megnyilatkozásának (Keating \& Fleming, 2009; Rácz és mtsai, 2016).

Abból indultunk ki, hogy a vizsgálat során a képek értékelése kvázi projektív felületként előidézi a vajúdás / szülés körüli érzelmi állapotokat és általános attitúdöket; majd a szabadon választott szüléstörténet elmesélése az interpretatív szövegalkotás szintjén tárja fel az egyén tapasztalásait és jelentésalkotását. Interjúalanyainktól egy olyan, saját gyakorlatból származó történetet kértünk, amely számukra a segítés szempontjából jelentőségteljes, és amelyben segító kapcsolati élményeik előtérbe kerülnek. Az interjú témáinak felépítése tölcsérszerü (Smith és mtsai, 2009) volt: az általános kérdések felől haladtunk az egyedi és konkrét szüléstörténet felé. Ha a szüléstörténet spontán nem, vagy csak érintőlegesen tartalmazta a kutatás szempontjából releváns témákat, a beszélgetés fonalához és tartalmához igazítva strukturált kérdéseket alkalmaztunk. A vizsgálati helyzet felépítését az 1. táblázatban mutatjuk be.

1. táblázat. A vizsgálati helyzet felépítése

\begin{tabular}{|l|l|l|l|}
\hline \multicolumn{1}{|c|}{ Eszköz } & \multicolumn{1}{|c|}{ Képválogatás } & \multicolumn{1}{c|}{ Szüléstörténet } & \multicolumn{1}{c|}{ Strukturált kérdések } \\
\hline Cél & $\begin{array}{l}\text { Általános } \\
\text { vélemények } \\
\text { feltárása, érzelmi } \\
\text { ráhangolódás }\end{array}$ & $\begin{array}{l}\text { Tapasztalatok } \\
\text { és interpretációk } \\
\text { feltárása }\end{array}$ & $\begin{array}{l}\text { Elhangzottak tisztázása, } \\
\text { önfeltárás elósegítése, } \\
\text { témák felvetése }\end{array}$ \\
\hline $\begin{array}{l}\text { Kérdések, } \\
\text { instrukciók }\end{array}$ & $\begin{array}{l}\text { Milyen a jó segítón } \\
\text { Ön szerint? }\end{array}$ & $\begin{array}{l}\text { Meséljen el egy } \\
\text { szüléstörténetet, ami } \\
\text { a segítés } \\
\text { szempontjából } \\
\text { jelentós; amiben } \\
\text { előtérben van a segítő } \\
\text { kapcsolat élménye. }\end{array}$ & $\begin{array}{l}\text { Hogyan alakult a } \\
\text { pályafutása? Hogy képzeli } \\
\text { el a jövót? Mennyire } \\
\text { és hogyan befolyásolnak } \\
\text { a saját szülésének } \\
\text { élménei? Hogyan küzd } \\
\text { meg a stresszel? }\end{array}$ \\
\hline
\end{tabular}

\section{Vizsgálati személyek}

A vizsgálatban 5 kórházi szülésznő, 5 bába és 4 dúla vett részt, összesen 14 fő. Az elkészült IPA interjúkból jelen tanulmányunkba négy szülésznőét 
választottuk ki elemzésre. ${ }^{2} \mathrm{Az}$ interjúalanyok nevét megváltoztattuk, az interjúk szövegében található anonimitást sértő utalásokat (pl. helyszínek, időpontok) felismerhetetlenné tettük. Mind a négy személy nagyjából harmincéves szülésznói tapasztalattal rendelkezik, a kórházi hierarchiában viszonylag magasan helyezkednek el, és sajátos, környezetüktől eltérő szemléletben dolgoznak. Adataikat a 2. táblázat tartalmazza.

2. táblázat. A vizsgálati személyek adatai

\begin{tabular}{|l|c|l|l|c|}
\hline \multicolumn{1}{|c|}{$\begin{array}{c}\text { Név } \\
\text { (kitalált) }\end{array}$} & $\begin{array}{c}\text { Életkor } \\
\text { (év) }\end{array}$ & \multicolumn{1}{|c|}{ Pozíció } & \multicolumn{1}{|c|}{ Munkahely } & $\begin{array}{c}\text { Hány éve } \\
\text { praktizál? }\end{array}$ \\
\hline Szilvia & 57 & nem múszakos szülésznő & fővárosi kórház & 30 \\
\hline Katalin & 60 & nem múszakos szülésznő & fővárosi kórház & 34 \\
\hline Éva & 56 & vezető szülésznő & kisvárosi kórház & 30 \\
\hline Rozi & 54 & szülésznő & kisvárosi kórház & 28 \\
\hline
\end{tabular}

\section{Kutatási elrendezés}

A kutatási felhívás szövege szándékoltan olyan személyeket szólított meg, akik - egyetértve a kutatás céljával - fontosnak tartják a szülés során létrejövő kapcsolatot, így motiváltak voltak a vizsgálatban való részvételben. A felhívás tartalmazott általános tájékoztatást a vizsgálati helyzetról, majd szóban, egyenként is tájékoztattuk a jelentkezóket. A beszélgetéseket diktafonnal rögzítettük és kiegészító jegyzeteket készítettünk egy előre elkészített segédlapra. A résztvevők írásbeli beleegyező nyilatkozatot is kitöltöttek. A vizsgálatra nyugodt körülmények között, időkorlátok nélkül, egyénileg megbeszélt időpontokban került sor. Az itt tárgyalt négy személy interjúja a munkahelyükön (kórházakban, vagy magánrendelőben) zajlott. A beszélgetés során reflektálva interjúalanyaink kapcsolati igényeire, úgy alakítottuk az interjúhelyzetet, ahogyan az nekik leginkább megfelelt. Előfordult, hogy a szüléstörténettel kezdődött az interjú, de ennek az ellenkezője is. Interjúalanyaink közül voltak, akik visszautasították a képválogatás feladatot, vagy annak bizonyos részeit (pl. hogy címet adjanak a képeknek). Résztvevőink hasonló intimitást és biztonságos légkört igényeltek, mint amit egy pszichoterápiás első interjú során, vagy mint amit vajúdás/szülés

\footnotetext{
2 Az egyik bábával rendhagyó módon lezajlott kutatási interjú anyagát pszichoanalitikus esettanulmányként publikálta az egyik szerzó (Székely, 2016). Egy másik tanulmányunkban két, a pályája elején levő szülésznővel készült interjút elemeztünk (Székely \& Csabai, 2017).
} 
során igényelnek a vajúdók (Argelander, 2006; Vajda, 2006). Minden érzelmi-indulati töltet, kérdés vagy kétely megjelenhetett újra a beszélgetések során, így a résztvevők „„élő” történeteket jelenítettek meg. Ezeken a történeteken az interjúkészítók sem tudtak „,kívül maradni", gyakran előfordult, hogy az interjúhelyzet interszubjektív, kapcsolati elemeit is bevontuk a szövegek értelmezésébe. Az átélésben, vagy magában a történet „húzóerejében" tapasztalt egyéni különbségek ellenére a résztvevők legtöbbször igényelték a visszajelzéseket, értelmezéseket, érzelmi ráhangolódást. Fontos volt számukra elbeszélniük a történetüket, újraélni, újraértelmezni a saját narratívájukat. A szüléstörténetet a segítő kapcsolat jellemzőinek kontextusában tártuk fel: rákérdeztünk arra, hogy a vizsgálatban résztvevőknek milyen a viszonya a különböző szakterületen dolgozókkal, munkájuk során milyen nehezító tényezőkkel találkoznak, hogyan küzdenek meg a streszszel, és hogyan befolyásolják őket saját szülésükkel és anyaságukkal kapcsolatos élményeik. Kíváncsiak voltunk, hogyan alakult pályájuk kezdete, és hogy hogyan képzelik el jövőjüket. Az interjúk során a képekkel kapcsolatban előre meghatározott kérdések közül nem kaptunk minden esetben mindegyikre értékelhetó választ. Ugyanakkor értékes vezérelvnek bizonyult a képekról kialakuló benyomások megfogalmazása, amely spontán irányította a beszélgetés fonalát.

Az elemzés és az értékelés során egységes egésznek kezeltük a vizsgálati helyzetben elhangzott szöveget, így biztosítva a transzferabilitást. Az elemzések különböző szakaszaiban az adatfeldolgozás nem volt egységes, egyrészt reflektálva az adott témákra és összefüggésekre, másrészt itt is törekedve a transzferabilitásra. Ennek megfelelően az összefoglaló táblázatok és értelmezések sem mutatnak teljesen egységes képet.

A teljes vizsgálati anyag lépcsőzetes felosztását az adatgyújtés sajátosságaira reflektálva alakítottuk ki. Az interjúk hanganyagából átiratokat készítettünk, majd az IPA módszertanának megfelelően (Rácz és mtsai 2015, 2016; Smith és mtsai, 2009) elemeztük: az elsődleges témákat, kulcsszavakat az átiratok bal oldali margóján gyújtöttük össze. Többszöri átolvasás után a jobb margóra jegyeztük a felmerülő témákat. A négy interjúban felmerülő témákat egyeztettük és értelmeztük, majd azokból nagyobb értelmezési egységeket hoztunk létre összevonással vagy viszonyítással, így jöttek létre a fótémák. Az egyes felmerülő témákat minden egyes résztvevő esetében ellenőriztük, hogyan jelenik meg az adott szövegben. Jelen tanulmány keretei között nincs lehetőségünk az elemzés és értelmezés alapos és mindenre kiterjedő bemutatására, így a segítő kapcsolat és a szakmai identitás kialakulásával és megélésével kapcsolatos eredményeket tárgyaljuk részletesebben, érintve néhány más, releváns témát is. 


\section{Eredmények}

\subsection{Az interjúelemzés kibontakozó témái}

Interjúalanyaink a segítő kapcsolati tapasztalataikat a segítői én változásainak, illetve a szakmai identitás kialakulásának témái mentén mutatták be. Ez a szövegek feldolgozásának hermeneutikai szintjén is tetten érhető: a szüléstörténetek legfeljebb a felét teszik ki a teljes interjú-átiratoknak, és a szakmai identitás, mint alapvető téma köré szerveződnek. Az interjúanyagok jelentős részét a személyek szakmai identitásának értelmezéséről, jelenlegi gyakorlatukkal való összefüggéseiről, fejlődésükről, múltról és jövőről való reflexiók alkotják, mind a négy személy esetében.

A segítói munka és a segítői identitás alakulásának két aspektusa jelenik meg eróteljesen a szövegekben. A szakmai identitás fejlődése fótéma nagy vonalakban a következőképpen írható le: hogyan van jelen a segító én a helyzetben; hogyan határozza meg magát segítóként; és hogyan helyezi identitásának kontextusába a segítést. A vajúdóval való kapcsolat főtéma lényegében a segítő kapcsolatot, mint önmagában értékes minőséget, vagy mint a segítés célját írja le. A felmerülő témákat tehát e két mintázatba, vagy főtémák rendszerébe csoportosítottuk. E viszonyrendszereket összefoglalva a 3-4. táblázatban mutatjuk be. A továbbiakban ezeket a fótémákat vesszük sorra.

Az IPA eredmények bemutatásának jellegzetessége, hogy az interjúalanyok hangsúlyosan ,jelen vannak” a szövegben, az ismertetés és értelmezés - más kvalitatív kutatási módszerekhez képest is - szokatlanul sok idézetet és eredeti kifejezést tartalmaz (Osborn \& Smith, 2009; Rácz és mtsai, 2016). Az interjúalanyainktól származó idézeteket dőlt betúvel szedve, idézőjelek között közöljük; néhány helyen szögletes zárójelben a szerzők kiegészitéseivel, az olvasó megértését megkönnyítendő.

\subsection{A szakmai identitás fejlődése}

Minden interjúalanyunk kiemelt jelentőséget tulajdonít az önismeretnek, ugyanakkor ezt különböző szinteken fogalmazzák meg: „olyat nem teszek, amit nem szeretném, hogy nekem, vagy a lányomnak tegyen valaki" (Rozi); "az ember kellö önismerettel rendelkezzen" (Szilvia); „a segító saját magával tisztában legyen, és rendben legyen" (Katalin). Az önismeretet, ugyanúgy, mint a segítői munkát, folyamatként szemlélik, és a történeteikben számos ponton utalnak arra, hogy honnan hová fejlődtek, illetve hová szeretnének eljutni. 
"Ha csak így visszagondolok, nem az, hogy harminc évvel ezelöttre, mert az persze, hiszen harminc évvel ezelött minden más volt, de most akár a 10 évvel ezelőtti jelenlétemre gondolok, vagy akár csak az 5 évvel ezelötti jelenlétemre, hogy megállás nélkül folyamatosan tanulok." (Szilvia)

Ugyanígy minden alkalommal megjelenik az igény az önreflexióra, a történések megértésére és rendezésére.

„... azzal is történjen egyfajta megbeszélés, feldolgozás, akivel történt a folyamat. Nekem is nagyon fontos a visszajelzések szempontjából, hogy mi az, ami jó, mi az, ami nem volt jó, tehát mindegyik tanulságos történet." (Szilvia) "Az elmúlt nagyjából tíz évben minden szülést leírok, három részböl áll a bábanaplóm: az egyik a sztori maga, a másik, hogy rajtuk mit látok, akár a páron, akár az anyán, és utána leírom, hogy én hogy voltam a dologban, ígyúgy." (Katalin)

A szüléstörténetek szerkesztettségüket tekintve illeszkednek ebbe az önreflektív értelmezési keretbe, lényegre törőek, interpretációk tarkítják óket, a hangsúly nem a történetek egyedi részletein, hanem az élmények interpretációján, a tanulságok megfogalmazásán van. A négy szülésznő közül hárman a legutóbbi szülés melletti munkájuk történeteit mesélték el, így - mivel viszonylag friss élményekről van szó - az interjúhelyzetben tovább formálódnak az interpretációk. A jelentésadás folyamatában interjúalanyaink tudatosan törekednek rá, hogy mind érzelmileg, mind megértési szinten 'helyre tegyék' a történeteket.

„... még mindig mozog bennem a történet. ... amikor bezáródtak, befejeződtek, leírtam, megbeszéltük, akkor, úgy mondjam, nekem, ami a történetböl tanulság, vagy elvihetö, az elvivödik, de maga a történet, és a kapcsolat kicsit távolabbra kerül, visszazáródik." (Katalin)

„Merthogy vannak nehéz történetek, amik nagyon megviselnek, még akár akkor is megviselnek, amikor kognitive tudom, hogy ez nem az én történetem, csak rajtam landol, és nekem... valakinek el kell vinni." (Szilvia)

Az önismereti igényességnek nemcsak személyes hozadéka van, hanem kifejezetten a munkához kapcsolható haszna is:

„De azok a veszteségek, a feldolgozatlanok, rendszeresen beúsznak a szülöszobára. És az ő [a segítók] összes cselekedeteiket, a félmondataikat, a mozdulataikat, az elvárásaikat, a szülés, a másik szülésének a kísérésében lépten-nyomon ott vannak, és inkább akadályoznak. Tehát az lenne egy korrekt, ha a se- 
gítő... és most nem csak a szülésznō... Hát, orvosokról ne is beszéljünk... De hogy ő maga tisztában legyen azzal, hogy ő hogy volt, hogy az ő gyerekei hogy születtek." (Katalin)

„... az önismeret az nagyon fontos, és a saját szüléseink élményének a feldolgozása. Mert ha nem dolgozzuk fel, akkor durván bejönnek. Ha feldolgozzuk, akkor csak így néha-néha egy-egy momentum." (Szilvia)

Ez utóbbi idézetekben megjelenik az önismeret privát, személyes élettörténethez kötődő aspektusa is, a saját szülésélmények rendbetétele, érzelmi megmunkáltsága.

„... tudom, hogy az [a méhösszehúzódás] mennyire fáj. És mindig átérzem. Tudom, hogy nem hisztizik." (Rozi)

Éva arról számol be, hogy látja és érzi a különbséget, ha ez az önismereti erőforrás még hiányzik:

„... szerintem azért nem árt, ha az ember átéli azt, amit a kismama, tehát... Vannak kolléganőim, akik nem szültek, ók is tudnak segíteni, nem arról van szó, hogy nem. De mélységében én azért profitálok abból, hogy megéltem, átéltem. Tudom, hogy milyen, és hát... valahogy több türelme van az embernek a másik felé. Merthogy ismerem azt is, hogy kolléganő, mikor még nem szült, és miután szült. És ő szavakba is öntötte."

Interjúalanyaink tehát megfogalmazzák, hogy nem csak szakmai, vagy kognitív szinteken kell megérteni a történéseket, hanem a szülésznők érzelmi munkájának is van jelentősége. Fontos, hogy a segítő „a saját érzéseivel azért kapcsolatban legyen" (Katalin). Mindennapi gyakorlatuk része a vajúdó/szülő nő történetének megtapasztalása, az ezzel járó esetleges érzelmi terhek elviselése, a segítő és a segített érzelmi bevonódásának azonosítása.

„És ezért gondolom, hogy fontos az önismereti munka, vagy olyan technikáknak a megtanulása, amik szerintem nagyon fontosak a segitö szakmákban. ... akkor ezt tudjuk azonositani, hogy ez az én érzésem, és nem a másik emberé. Ezek az én gondolataim, és nem biztos, hogy az ő javát szolgálják." (Szilvia) „... a segítő saját magával tisztában legyen, és rendben legyen. ... Mert hogyha nincsen tisztában, akkor nem látja a segítettjét. Tehát, hogy nem látja azt, hogy mi volt az ô döntésének a saját... tehát, hogy mitől döntött így." (Katalin)

Interjúalanyaink tapasztalt, jól képzett szülésznők, akik nagyjából harminc éves gyakorlatuk során több ezer szülés mellett segítettek már. 
A szakmai fejlődésükben jelentős szerepet tölt be a vajúdótól, a vajúdóval való kapcsolatból való tanulás:

„Nahát, tulajdonképpen a nők tudnak szülni, anélkül is, hogy mi itten rengeteg dologgal úgymond segítenénk, merö jó szándékból. És hogy úgy elkezdtem figyelgetni a nóket. Onnantól kezdve igazából a tanulási folyamat igazából már a tólük való tanulás volt." (Szilvia)

"És itt nekem bebizonyosodott, hogy igenis a kismamáknak a megérzéseire nagyon-nagyon lehet alapozni, és elég, ha csak ott vagyunk, és szemléljük a dolgokat. Az a legjobb, hogyha nem kell belenyúlni a folyamatba, és nagyon szépen tud müködni." (Éva)

Interjúalanyaink szakmai szemléletmódja nem általános, sőt ritkaságnak számít munkakörnyezetükben.

„... általában, és a bent dolgozó kolléganőinknek a nagy része, az ... úgy könyvel el, hogy egy kicsit hóbortos vagyok. De nem baj ... ha ôk ezt így látják, én ezt felvállalom. Tudom, hogy miért gondolják azt, merthogy másképp müködöm ebben az egész várandósgondozás, meg szülés történetben." (Szilvia) "Ha olyan kolléganôvel van az ember, meg olyan orvossal, aki úgy engedi, hogy dolgozzunk, és a kolléganő is tapintatos. Tehát, hogyha ő is hasonló szemléletü. [De ha nem,] ... nagyon nehéz... mert nem érti a másik, hogy miről van szó." (Rozi)

"Fontos volt, hogy szüléseknél segitsek, tehát nem az motivált, hogy úristen, végigaludjak egy éjszakát, és ne jöjjön senki. Valahogy nekem az mindig kihivás volt, hogy ú, ha jött valaki, akkor én annak örültem. Van ellentét is [a szülésznő kollégákkal], igen. Itt is. Nem is biztos, hogy tehet róla, mert ő is emberböl van." (Éva)

A szövegekből kiderül, hogy a medikalizált, hierarchikusan szervezett kórházi körülmények számos kapcsolati konfliktus forrásaként jelenhetnek meg, ugyanakkor úgy túnik, interjúalanyaink magas pozíciója jelentősen csökkenti ezek előfordulását. Katalin és Szilvia csak alkalmanként dolgoznak múszakban, és vállalt szülésekhez járnak a kórházba. Éva vezető szülésznő, ami szervezési munkát jelent, rögzített, nappali múszakban, tehát szülések mellé csak saját választása esetén kerül. Rozi ugyan nem vezetó szülésznő, és múszakban dolgozik, de évtizedes gyakorlatával és szemléletmódjával kapcsolódik a saját munkahelyén a hasonló szemléletú vezető szülésznőhöz, így a státusza viszonylag magas. Ez a polarizáció az orvosokkal való kapcsolatban is megjelenik, és itt is jellemző, hogy a magas státusz legalább részben biztosítja a konfliktusok elkerülésének lehetőségét, azaz a hasonló szemléletú orvosokkal való együttmúködést. 
„... Nekünk ez így kényelmes, merthogy így mi is biztonságban érezzük magunkat. Nem arra megy el az energiánk, hogy egy olyan orvossal kell konfrontálódnunk, akivel meróben ellentétes a szemléletünk. És hát ez persze nagyon szolgálja a családnak is az érdekét, mert hogyha egy jó összhang van ... akkor az nagyon pozitív hatású." (Szilvia)

„Sokszor nehéz. Sokszor nehéz... A nyugodt, és... tehát a hasonló temperamentumú szülészorvosokkal tudok jól együttmüködni. Aki nagyon beavatkozós, vagy ö, mint orvos meg akarja oldani a szülést, vagy mint ezt a problémát kezeli, azokkal kevésbé tudok együttmüködni. És ebböl szoktak származni konfliktusok. Hát szerintem azért valamilyen szinten elfogadtak így, hogy én nem ahhoz a pólushoz, vagy nem ahhoz az oldalhoz tartozom, aki az orvos asszisztense, hanem van önálló megérzésem, meglátásom, és cselekedetem. És szokták nehezményezni azért, föleg az idősebb orvosok, hogy nekem, mint vezetô szülésznőnek nem ezen az oldalon kéne állnom. A bábai oldalon. Merthogy az a jó szülésznö, sokak szerint, aki azt csinálja, amit az orvos mond. ... És én meg mondtam, hogy nem." (Éva)

Éva itt rávilágít egy rendszerszintú problémára is, amely minden résztvevőt személyesen is érint, interjúalanyainkat különösen: a tapasztaltabb, gyakorlottabb szülésznők ,önállóan is tudnak dolgozni”, ,nagyon jó elméleti alapokat” kaptak a szülésznőképzésben, és tudják, hogy „az a jó szülés, ahol minél jobban csak a végén látjuk az orvost". Ugyanakkor a kórházi protokoll előírásai és a hierarchikus múködésmód a szülésznők önálló munkavégzését nyíltan és hivatalosan nem teszik lehetóvé, csak kivételes, saját megoldások születhetnek: „nagyon jó, akikkel össze vagyunk szokva”; „beláthatók a határok, meg a keretek ebben a kapcsolatban”. Katalin ezzel kapcsolatban arról is részletesen beszél, milyen érzelmi hatásai vannak az orvosokkal való szemléletbeli és hatalmi különbségeknek:

„... alapjában véve ez egy feudális, hierarchikus kapcsolat, ami alig tud változni. ... Ha müszakba vagyok osztva, és nem saját örömömre dolgozom, akkor ezt a hierarchiát nagyon meg kell tartanom, és rengeteg feszültséget okoz, merthogy nem tudom megvédeni az anyát az orvosnak az abuzálásától, vagy a rendszer abúzusától. Ami méltatlan és nagyon sok feszültséget ad. És egy ilyen lojalitás-háborút magamban." 


\begin{tabular}{|c|c|c|c|c|c|c|}
\hline $\begin{array}{l}\stackrel{N}{0} \\
\cong\end{array}$ & 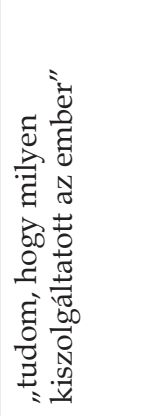 & 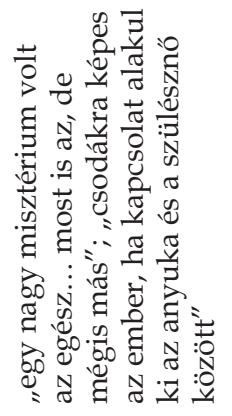 & 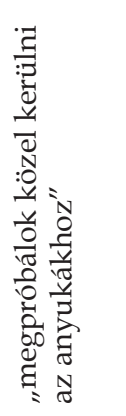 & 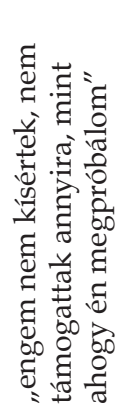 & 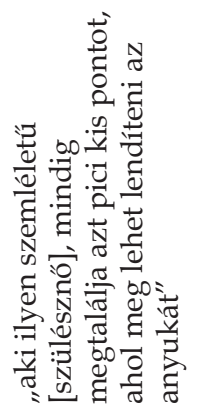 & 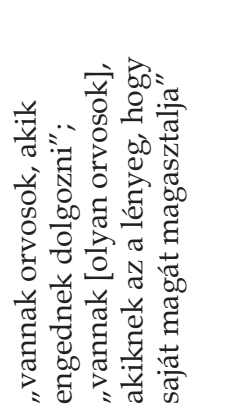 \\
\hline 空 & 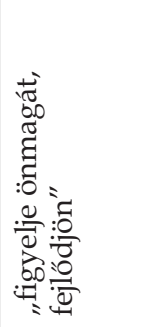 & 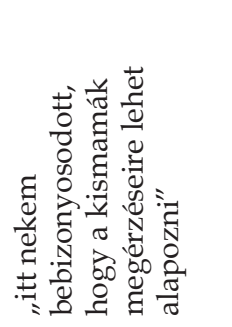 & 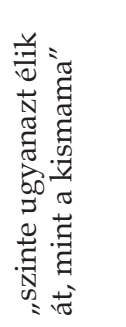 & 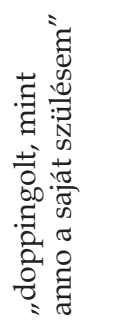 & 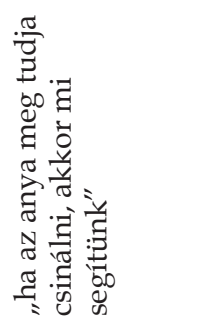 & 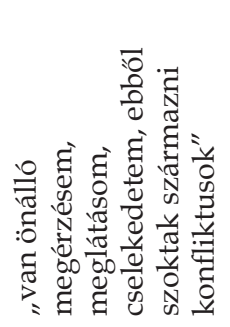 \\
\hline 胥 & 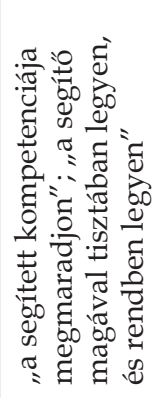 & 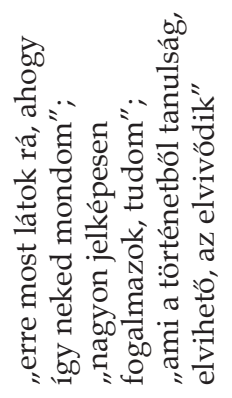 & 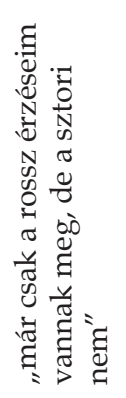 & 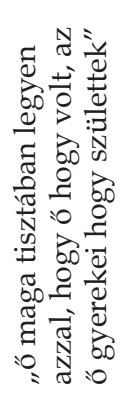 & 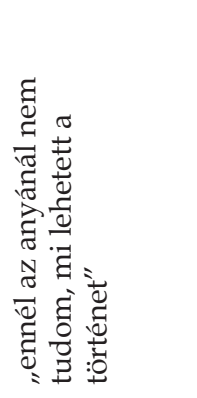 & 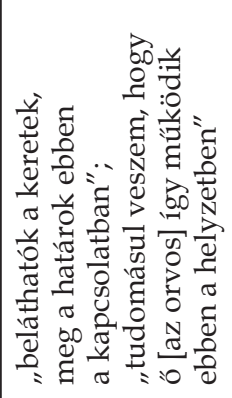 \\
\hline 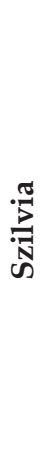 & 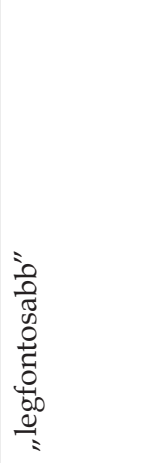 & 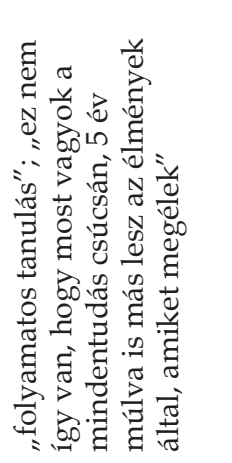 & 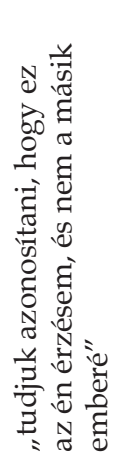 & 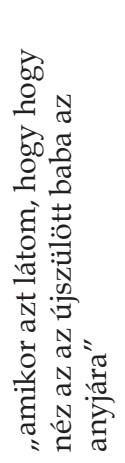 & 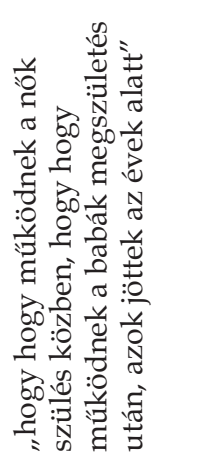 & 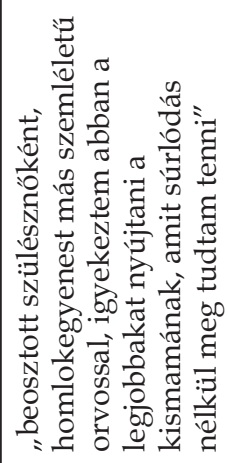 \\
\hline 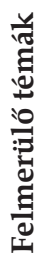 & 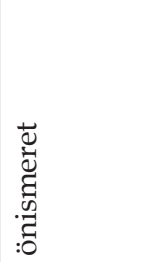 & 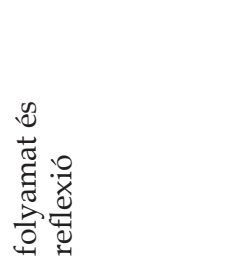 & 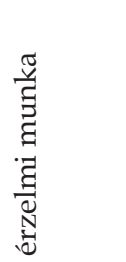 & 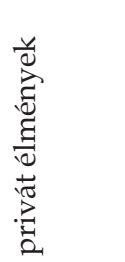 & 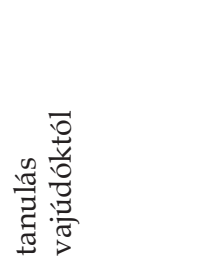 & 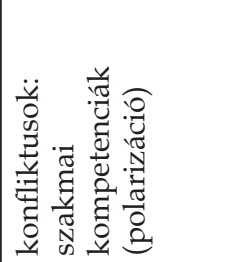 \\
\hline
\end{tabular}




\subsection{A vajúdóval való kapcsolat}

Interjúalanyaink tehát elengedhetetlennek tartják a munkájuk során a vajúdóval való jó minőségú kapcsolat kiépítését. Ez jellemzi és meghatározza a munkájukat, és alapvetően érzelmi odafordulást, személyes törődést jelent számukra.

„Az én szüléstörténeteim annyira személyesek. És ... azt hiszem, hogy nem az anyák miatt személyesek, hanem miattam személyesek. Tehát, az én együttlétem velük teszi nagyon személyessé. És azzal, ahogy együtt... mozgok a családdal, igazán... együtt vagyok a családdal valahogy." (Katalin)

Előfordul, hogy ez a munkamód kórházi körülmények között nehezen megvalósítható, és amikor hiányzik a megfelelő kapcsolat, a segítői munka is megváltozik.

"Nagyon nehéz volt vele dolgozni. ... Nem tudtunk kapcsolatot teremteni." (Rozi)

Ugyanakkor a segítés jelentős fizikai törődést is jelent: az érintés, maszszázs, folyamatos jelenlét tovább mélyíti, személyesebbé teszi a vajúdóval való kapcsolatot.

„És amikor eljön az a pillanat, hogy odamehetek, és csak egy érintés, vagy végigsimítom, és ettől örajta olyan nyugalom... és olyan biztonságérzet alakul ki benne." (Rozi)

Ez fordítva is igaz: csak egy bizalmi kapcsolatban lehetséges a személy intimitáshatárait átlépni anélkül, hogy megsértenénk.

„Hát nyilván ugye, ha az ember müszakba kerül oda, akkor fogalmam nincs [milyen állapotban van a vajúdó]. És, hát akkor kell kezdeni egy rapportépitéssel." (Szilvia)

„Nem kaptam rá jelzést, nem kaptam rá felhatalmazást, hogy... az érintésre, vagy a közeledésre, tehát a határokat ő szabta meg, mondjuk a szülésnél, a közelséget, a távolságot. És semmilyen jelzést nem adott arra, hogy közelebb lehet lépni." (Katalin)

Katalin a kapcsolat intenzitását, változásait, és annak interpretációját hangsúlyozza:

„... hogy a 9 hónap alatt, vagy a 10-11 hónap alatt, attól függ, hogy mennyi időt töltünk együtt a várandósság előtt, és a gyermekágyas időszakban; úgy 
visszaadódik a kapcsolat minősége, visszahül ... vissza kell, hogy adjuk a kapcsolatot, a kapcsolatnak a minőségét, vagy a melegségét arra a távoli szintre, amiben [azelött] voltunk."

Az érzelmi kapcsolat tehát a vajúdás/szülés idejére szól (gyakran a várandósság is ide tartozik), nagyon intenzív és személyes, ugyanakkor sokszor komoly önismereti munkát is igényel, ahogyan ezt a szakmai identitás fejlődése főtémánál is kifejtettük. Mindkét fél hozhat a kapcsolat közös terébe olyan személyes történeteket, amelyek nem a másik félnek szólnak, mégis megjelennek és megterhelik a közös munkát.

„... az ember hónapokon keresztül sok időt tölt egy kismamával, és megismerjük egymást, és sok minden kiderül az ô elötörténetéből, esetleges félelmeiből, szorongásaiból. De persze olyan is van, hogy nem is gondolja, hogy valamit elmeséljen, és a szülésnél mutatkozik meg, vagy éppen az utolsó ctg vizsgálatnál borul ki a csontoáz a szekrényből." (Szilvia)

„... egy-két nap alvás után, meg ahogy leírom, rájövök arra, hogy hol vagyok én ebben a történetben. ... ez most azért nehéz, merthogy azt hiszem, hogy érzelmileg jobban ott voltam, mint egyébként a profi segitó. Jobban megérintödtem..." (Katalin)

Az anyai gondoskodás természetes módon jellemzi a segítők munkáját és a vajúdóval való kapcsolatot is meghatározza. Ugyanakkor láthatjuk, hogy a személyes megérintődésekre is kaput nyit.

„Érzelmileg meg nem maga a [saját] szülés az, ami megmozgat engem, hanem az anyaság... jaj istenem, hát én is anyuka vagyok." (Szilvia) „... nagyon, nagyon bemozgatta az én anyai minóségeimet” (Katalin)

Interjúalanyaink interperszonális és intraperszonális konfliktusokról is beszámolnak: gyakran előfordul, hogy a más szemléletben dolgozó kollégákkal kerülnek nyíltan szembe, vagy alkalmazkodnak ugyan, de a konfliktus intrapszichésen tovább zajlik. Ez nyilvánvalóan hatással van a vajúdóra is, mert általában a medikalizáció és/vagy a háborítatlanság szemléleti és gyakorlati kérdéseit foglalja magába.

„... vannak olyan orvosok, akiknek az a lényeg, hogy ő saját magát magasztalja. És a saját képességeit hirdesse. És az ilyeneknél nem lehet úgy támogatni egy vajúdást, ahogy kellene..." (Rozi)

„... az már régen rossz, amikor így, tehát amikor mintegy ütköző vagyok két ember [a vajúdó és az orvos] között, oda nem jó energiák fognak bejönni. És nincs az a pókerarc, amit föl lehet venni, hogyha kint valamin összevitatko- 
zunk - én igyekszem a kismama érdekeit képviselni, még ha akár idézőjelesen mondom, gyözök abban a csatában, de azt a feszültséget beviszem." (Szilvia) "Aztán még a doktorno" is fölvette a kezébe a babát, és megpróbálta vigasztalni. Amitól bennem már akkor nagyon-nagyon... nagyon-nagyon erös tiltakozás volt bennem... Ez nagyon érdekes volt, és még mindig mozog bennem a történet. Nagyon-nagyon rossz érzés volt." (Katalin)

4. táblázat. Főtéma: Vajúdóval való kapcsolat ${ }^{3}$

\begin{tabular}{|c|c|c|c|c|}
\hline $\begin{array}{l}\text { Felmerülő } \\
\text { témák }\end{array}$ & Szilvia & Katalin & Éva & Rozi \\
\hline $\begin{array}{l}\text { érzelmi } \\
\text { támasz }\end{array}$ & $\begin{array}{l}\text { „kezdek egy } \\
\text { rapport- } \\
\text { építéssel”; } \\
\text { bizalmi } \\
\text { kapcsolat }\end{array}$ & $\begin{array}{l}\text { "a benne } \\
\text { levésünk } \\
\text { a nehéz"; } \\
\text { közös } \\
\text { folyamat }\end{array}$ & $\begin{array}{l}\text { „nagyon közel } \\
\text { hozott } \\
\text { bennünket } \\
\text { egymáshoz" }\end{array}$ & $\begin{array}{l}\text { "nem tudtunk } \\
\text { kapcsolatot } \\
\text { teremteni" }\end{array}$ \\
\hline fizikai támasz & $\begin{array}{l}\text { "folyamatosan } \\
\text { ott voltam } \\
\text { mellette" }\end{array}$ & $\begin{array}{l}\text { "a határokat ő } \\
\text { szabja meg” }\end{array}$ & $\begin{array}{l}\text { "testi jelenlét"; } \\
\text { "érintés, } \\
\text { masszázs" }\end{array}$ & $\begin{array}{l}\text { „masszíroz- } \\
\text { gattam” }\end{array}$ \\
\hline $\begin{array}{l}\text { anyai } \\
\text { gondoskodás }\end{array}$ & $\begin{array}{l}\text { „jajistenem, hát } \\
\text { én is anyuka } \\
\text { vagyok" }\end{array}$ & $\begin{array}{l}\text { „'nagyon } \\
\text { bemozgatta } \\
\text { az anyai } \\
\text { minőségeimet” }\end{array}$ & $\begin{array}{l}\text { „segíteni fogjuk, } \\
\text { hogy úgy } \\
\text { legyen, ahogyan } \\
\text { o szeretné” }\end{array}$ & $\begin{array}{l}\text { "nyugtat- } \\
\text { gattam" }\end{array}$ \\
\hline $\begin{array}{l}\text { önmegtapasz- } \\
\text { talás }\end{array}$ & $\begin{array}{l}\text { "folyamatos } \\
\text { tanulás" }\end{array}$ & $\begin{array}{l}\text { "nagyon rossz } \\
\text { érzés volt" }\end{array}$ & $\begin{array}{l}\text { "annyira } \\
\text { feltöltött, hogy } \\
\text { én utána nem } \\
\text { tudtam aludni" }\end{array}$ & $\begin{array}{l}\text { „nekem ez } \\
\text { olyan megrázó } \\
\text { volt: nem } \\
\text { jellemzó rám, } \\
\text { hogy nem } \\
\text { nyílnak meg” }\end{array}$ \\
\hline $\begin{array}{l}\text { konfliktusok: } \\
\text { háborítat- } \\
\text { lanság vs. } \\
\text { medikalizáció } \\
\text { (polarizáció) }\end{array}$ & $\begin{array}{l}\text { „elmegy az } \\
\text { energiánk"; } \\
\text { "háttérbe } \\
\text { húzódom”; } \\
\text { az orvos } \\
\text { szemlélete } \\
\text { határozza meg }\end{array}$ & $\begin{array}{l}\text { „'nem tudtam } \\
\text { őket megvédeni } \\
\text { magunktól”; } \\
\text { a segítés } \\
\text { kudarca }\end{array}$ & $\begin{array}{l}\text { az orvosok } \\
\text { „szerint nem } \\
\text { ezen a [bábai] } \\
\text { oldalon kéne } \\
\text { állnom”; } \\
\text { „kellemetlen, } \\
\text { nehéz etikusnak } \\
\text { maradni" }\end{array}$ & $\begin{array}{l}\text { "olyan nagyon } \\
\text { nem tudtam } \\
\text { támogatni oot, } \\
\text { mert épp } \\
\text { múszakban } \\
\text { voltam" }\end{array}$ \\
\hline
\end{tabular}

3 A táblázatban idézőjelek között közöljük az interjúalanyok szövegeit, néhány helyen összefoglaló megjegyzésekkel ellátva (idézőjel nélkül). 


\subsection{A szakmai identitás és a vajúdóval való kapcsolat értelmezései}

A két főtéma számos ponton van egymással szoros összefüggésben, több szempontból kölcsönösen definiálják egymást, azaz „egyikből következik a másik": a szakmai identitás a megélések reflektív és összegző szintje, ahol a megértés, rendszerezés, fejlődés igénye megjelenik és személyessé válik; a vajúdóval való kapcsolat pedig a fejlődés tapasztalati szintjét képviseli, ahogyan munka közben formálódnak az eleven élmények. A segítés érzelmi minősége a segítő folyamatos önismereti munkájának az eredménye, ugyanakkor a segítésben, a vajúdóval való kapcsolatban zajlik ez az önismereti folyamat, a segító én megtapasztalása, kibontakozása és fejlődése. A polarizáció, a tapasztalatok és élmények ellentétes viszonyrendszereken keresztül való meghatározása, elméleti síkon a szemléletmódok ütközéseként, gyakorlati síkon a medikalizációt képviseló kollégákkal (orvosokkal és szülésznőkkel) való konfliktusos kapcsolatokban realizálódik. A „hóbortos” szülésznőket megtúrik, megengedik nekik az eltérő viselkedést és szemléletet, mert az intézményes hierarchiában elfoglalt pozíciójuk biztosítja számukra a viszonylagos önállóságot. A két szemlélet: a vajúdó személyes kísérése és/vagy a medikalizált protokoll követése szinte átjárhatatlannak túnik. Interjúalanyaink járják az összeegyeztetés „hosszú és göröngyös” útját, de ahogy Katalin fogalmaz: „nem tudtam óket [a családot] megvédeni. De hogy nem magunktól kell... persze magunktól kellett volna megvédeni óket, de hogy ezek szakmai döntések voltak". Úgy túnik, folyamatosan kettős szerepben vannak: vagy sikerül a saját szemléletükben, önállóan dolgozniuk, vagy a rendszer részeként protokolláris ellátást nyújtanak, miközben ez „belső fájdalmat vagy nehézséget okoz". Interjúalanyaink esetében magas státuszú szülésznőnek lenni privilégium, amely komoly munka eredményeképpen jött létre, és jól meghatározható előnyökkel jár. Szakmai elkötelezettségük révén a vajúdók érdekében élnek is előjogaikkal, és igyekeznek enyhíteni az rendszer múködéséból adódó „károkat”. Ugyanakkor nem függetlenek a rendszertől, önmagukat is így határozzák meg, egyedül Rozi fogalmazza meg, hogy intézményen kívül is kipróbálná a szüléskísérést, de ez csak egy „vágyálom".

Szemléletükben is tükröződik a kettős szakmai identitás: „,középpontban a segített... álljon, illetve annak az igényei, és annak a kompetenciáinak a megtartása. ... [de] a szakmai rész az ne a segítés alá kerüljön." Eszerint tehát előfordul, hogy a személyes, érzelmi támogatással járó szüléskísérés ellentmondásba kerül a szakmai szempontokkal, amely a gyakorlatban a beavatkozásokkal kapcsolatos döntéseket jelenti:

"Hogyha egy szakmai döntést kell hozni, akkor érzelmileg ne döntsünk." (Katalin) 
„... élettani szülésre készültünk, ugye azért ez mindenképp egy előny. Ilyenkor azért az ember megengedóbb akkor a protokolltól jobbra, balra eltérni..." (Éva)

A magas státusszal együtt járó további elóny, hogy interjúalanyaink saját mentális és fizikai erőforrásaikhoz jobban hozzáférnek, többnyire maguk szabályozzák munkarendjüket, legtöbbször döntést hozhatnak, mennyi szülést vállalnak el. Rozi a múszakos munkát is így éli meg: „én itt élem ki magam, én itt teljesedek ki". Ugyanakkor, az egészségügyi ellátórendszer, és ezáltal a dolgozók túlterheltsége miatt, interjúalanyaink erőforrásait a medikális szemléletú, kötöttebb és kiszolgáltatottabb helyzetben dolgozó kolléganőik 'kihasználják':

„azok, akik bent dolgoznak... nyilván az ő más gondolkodásuk és üzemmódjuk miatt egy kicsit hóbortosnak tartanak minket, és akkor hát így most csúnya szóval mondom, tehát a »hülye kismamákkal azokkal foglalkozzunk mi. Tehát ez nagyjából így szokott elhangozni." ... És akkor mondták, hogy ez [a »hülye kismama «] neked jó lesz. Mondtam, hogy ó, én meg boldogan vállalom." (Szilvia)

Interjúalanyaink arra is rálátnak, hogy a medikális és személyre szabott szülészeti szemlélet közötti ellentét egyik lehetséges oka az érzelmi távolságtartás, kiégés (Hunter, 2001; Kovács, 2006).

„... nagyon sokszor láttam, és látom is azt, amikor egy szülésznő a nagyon is szüken vett szülésznői feladatát csinálja. Tehát remekül tud, nem tudom, vizsgálni, szívhangot hallgatni, gátat védeni, szükség szerint bekötni az infúziót, a helyzetet értékelni, és aszerint a megfelelő megoldásokat meghozni. De hogy keveset vannak bent a szülöszobán a kismamával. Aminek, hát biztos, nyilván számtalan oka van, én úgy látom, hogy sokszor egyfajta érzelmi távoltartás, vagy ez az »énhatáraimnak a nagyon szigorú tartása az, ami miatt, mint egy védekező reakció tud így müködni, hogy kevésbé érintődjek meg érzelmileg, mert akkor saját történetek is be tudnak mozdulni." (Szilvia)

Az elemzés során megfigyeltük, hogy a szüléstörténetek legfóbb rendezőelve a siker/kudarc dimenzió. Sikerült-e megvédeni a rendszertől a vajúdót és a kisbabát, sikerült-e kapcsolatot teremteni vele:

„... nekem ez olyan megrázó volt, hogy tényleg nem jellemzö rám, hogy nem nyílnak meg az anyukák előttem, és hogy nem tudok közel kerülni hozzájuk. És ebben az egy esetben úgy érzem, hogy ez negatív volt, mert ez nem ment úgy, ahogy kellett volna. ... Nem tudtam öt úgy megnyitni, ahogy kellett volna." (Rozi) 
Katalin történetéból már többször idéztünk más összefüggésben, hogy „nem tudta megvédeni” a vajúdót, és nem sikerült „profi segítóként” viselkednie, mert „nagyon bemozgatta az anyai minóségeit”.

Szilvia sikertörténetében a „nagyon ziháló, levegőt kapkodó, kicsit túlmozgásos” vajúdó végül lecsillapodott attól, hogy ő „boldogan elvállalta” a segítségnyújtást.

„És ez a kismama teljesen rá tudott ülni a szülésnek a hullámaira. Egy óra múlva itt már... idézójelesen mondom semmiféle hisztériás reakciók nem voltak, ami nyilván nem hisztéria volt, hanem az ő kibillent helyzetében, meg az idegen helyzetból adódó dolog." (Szilvia)

A történetek egy másik rendezőelve az „elvihető" tanulságok, tapasztalatok és összefüggések felfedezése, megfogalmazása, amely összekapcsolódik a szakmai identitás formálódásával, az önismereti igénnyel.

„Kiderült, hogy ez a baba ez egy nem várt baba volt. ... Tehát azért itt rengeteg félelmet és szorongást vitt magával ez a kismama, ... amikor szembesülni kell azzal, hogy itt pedig szülés lesz. Itt pedig gyerek lesz. Ez sok szempontból megijesztette ôt. És sikerült ôt visszabillenteni ôt egy olyan helyzetbe, ami egy normál szülési folyamat, és tizenegy órára megszületett a baba. ... És hát... ki nem adta volna a kezéból ezt a gyereket. És, hogy nekem azért volt nagyon szép ez a történet, merthogy én belecsöppentem egy nagyon nehéz helyzetbe, aminek fogalmam sem volt, hogy mi az oka, de amit lehetett látni, az az, hogy valami rettenetes nagy szorongás és félelem a háttérben. És nyilván persze, a magam részéról is, hogy hát ezt sikerült jól megoldani, ez egy sikerélmény volt. Utána megkaptam hozzá a kognitív muníciót is, hogy... tehát, amikor már megtudtam, hogy mi vezetett ide." (Szilvia)

„... igazából nem a szakmai rész, ha szúken veszem, a manuális, meg a tudományos része az, ami ebben nehéz, hanem a ... benne levésünk. És a kilépésünk. Igen. És ezekből a történetekből [ahol megérintődik], gyakran sokkal nehezebb kilépni. Igen, hogy viszem magammal." (Katalin)

\section{Megvitatás}

Az interjúszövegek átiratainak elemzése során a felmerülő témákat két főtémába csoportosítottuk: a szakmai identitás fejlődése és a vajúdóval való kapcsolat minősége, amelyek egymást kölcsönösen meghatározó lényeges elemei a szülés során létrejövő segítő kapcsolatnak. A beszélgetések fonalát a szakmai identitás bemutatása adja, ebbe az értelmezési keretbe illeszkedik a kiválasztott szüléstörténet: interjúalanyaink számára fontos a tudatos önreflexió, a történések interpretációja és személyes fejlődéstörténetükben és élettörténetükben való elhelyezése. 
Az itt bemutatott négy interjú viszonylag kiegyensúlyozott, kevésbé polarizált történeteket mutat be. A segító kapcsolatban a segító általában ki van téve a segített traumájának, a másodlagos traumatizáció kockázata igen magas (Fülöp, 2013). Interjúalanyaink megküzdési képességei, továbbá munkakörülményeik lehetôvé teszik, hogy legtöbbször „fáradtan, de boldogan" jöjjenek ki a történetből. Azokon a munkaterületeken, ahol a szélsőséges helyzetek szinte mindennaposak, a segító kapcsolat is további nehézségekkel terhelődik, így a segítő foglalkozású szakemberek kiégésének kockázata többszörös lehet (Fülöp, 2013; Kovács, 2006). A segítő/gyógyító tevékenység egyik legfontosabb összetevője az érzelmi munka (Csabai, Csörsz, \& Szili, 2009; Kovács, 2006), hiszen - amint interjúalanyaink is megfogalmazták -, a „,bensőséges” segítő kapcsolatban „az érzelmek nagyon érdekes utakon tudnak közlekedni", és vannak „,nagyon nehéz szülések, amik mentálisan nagyon igénybe veszik az embert". A megnövekedett stresszre kórházi körülmények között legtöbbször érzelmi távolságtartással reagálnak a segítő foglalkozásúak. Ezt a folyamatot érzelmi munkára képes interjúalanyaink is megtapasztalják: a „hóbortos” jelző devalválja interjúalanyaink munkáját, nem ismeri el releváns szakmai kompetenciaként az érzelmi támasznyújtást, erősítve a tételt, hogy ha az ellátás olyan emberek érzelmi szükségleteivel kapcsolatos, akik szenvedést, fájdalmat, vagy traumát élnek át, az a szaksegítókben is traumatikus stresszreakciókat indíthat el (Leinweber \& Rowe, 2010). Az érzelmi támasznyújtás ugyanakkor szakmai kompetenciaként tanulható és tanulandó képesség (Hunter, 2001).

Úgy túnik, minél alacsonyabb státuszú valaki a kórházi hierarchiában, annál kevésbé van szabad választása a vajúdónak való segítés módjait illetően. A medikalizált, protokolláris ellátás szigorú normaként interpretálódik (Kisdi, 2012; Kitzinger, 2008; Varga, 2015; Varró, 2015). Interjúalanyaink a hierarchikus, többnyire személytelennek megélt kórházi körülmények között igyekeznek fenntartani és múködtetni egy páciens- és nőközpontú szemléletmódot, de mindannyian megélik, hogy ez saját munkájukba csak „finoman, lassacskán épül be", mert ez egy nehezen változó, számos anomáliától terhelt viszonyrendszer. A vezető szülésznő nővérszinten van a hierarchia csúcsán, de a szülészorvos „engedi”, vagy éppen „neheztel”, ha önálló döntései és cselekedetei vannak. A saját szülésekhez járó szülésznők, ha múszakba kerülnek, legfontosabb feladatuknak tartják, hogy betartsák a protokolláris szabályokat. Amikor azokkal az orvosokkal dolgozhatnak "akikkel össze vannak szokva”, és hasonló a szemléletük, vagy „a pártjukon lesz", akkor érzik magukat biztonságban. Úgy túnik tehát, hogy minden szakmai önállóságuk ellenére az orvos biztosítja a szülésznóknek a független munkavégzést. Ez az üvegplafon jelenségeként is értelmezhető, amely számos szakmában és munkahelyen megfigyelhető társadalmi egyenlőtlenség a nemek között: bármilyen magasra is jut a nő a munkahelyi 
vagy szakmai hierarchiában, egy bizonyos szint fölé nem kerülhet (Fox \& Hesse-Biber, 1984; Judge \& Livingston, 2008). Úgy túnik, a kétféle, szülésznő-bábai és szülészorvosi szaktudás jelenleg még nem válhat egyenrangúvá.

Az egymásnak ellentmondó szemléletek polarizációja kezelhető keretek között marad interjúalanyaink esetében, tisztában vannak a medikális és a kapcsolatorientált munka összebékíthetetlen „üzemmódjaival” és különbségeivel, ugyanakkor ",ami rendelkezésükre áll, hogy lépjenek, vagy tegyenek", azt megpróbálják. Segítői identitásukban is tükröződik ez a kettősség, igyekeznek elkerülni azokat a helyzeteket, ahol nincsenek ,"biztonságban”, és „lojalitás-háborúba” keveredhetnek. A szüléstörténeteket sikeresnek vagy kudarcosnak értékelik, aszerint, hogy a medikális protokollhoz képest mennyire lehetett ",jobbra-balra eltérni", vagy alkalmazni kellett a "teljes arzenált, amit a kórház fel tud hozni a medikalizáció jegyében". Ez a narratív szervezőelv lényegében a kapcsolatorientált segító munka sikerességére vagy kudarcára utal a személytelen protokolláris ellátással szemben, amelyet interjúalanyaink „,személyes sikerélményként” vagy kudarcként könyvelnek el.

A kapcsolat élménye, minősége, légköre alapvető fontosságú, hiszen a gyógyító kapcsolat a gyógyítás nem specifikus hatótényezője (Csabai és mtsai, 2009; Fülöp, 2013). Interjúalanyaink is megerősítik, hogy a biztonságos vajúdás/szülés elengedhetetlen összetevője a jól múködő segítő kapcsolat. Fontos, hogy „megnyílik-e” a vajúdó a segító felé, „intenzív együttlét” jellemzi a segítő kapcsolatot, és „van a szülésnek egy dinamikája, vagy egy temperamentuma, ami a segítókre is rányomja a bélyegét". A segító számára nagyon "személyes" a segítés élménye, "együtt mozognak", ugyanakkor a szülést kíséró segítő a biztos pontja, a valóságban lehorgonyzott szereplóje a közös élménynek (Lundgren \& Dahlberg, 2002). A vajúdás/szülés tekinthető egyfajta átmeneti jelenségnek, határhelyzetnek is, amelyben a pszichés történések interszubjektív térben zajlanak (Lundgren \& Dahlberg, 2002; Winnicott, 2004). Interjúalanyaink szerint nagyon fontos, hogy a segítő "valamennyire azért a saját érzéseivel is kapcsolatban legyen”, rendelkezzen önismerettel, a saját története „megcsituljon” és „feldolgozódjon". A segító kapcsolat dinamikája szervesen kapcsolódik minden résztvevő élményéhez. A segítői identitás alakulása hasonlóképpen leírható az út metaforájával, mint a vajúdás/szülés folyamata, ráadásul ez a két út számos ponton közösen halad, ahogyan azt a két főtéma elemzésénél láthattuk (Dima \& Bucuta, 2012; Rácz és mtsai, 2016). A kapcsolatban kibontakozó önmegtapasztalások táplálják a segítő identitást, és a segítői identitás alapvető meghatározója a vajúdóval való kapcsolat hangsúlyozása. A vajúdás/szülés során létrejövő segítő kapcsolatot tovább elemezhetjük Winnicott (2004) „én-kapcsoltság” fogalmát metaforaként használva. Ebben 
a feltételezett ellazult állapotban, biztonságos kapcsolati környezetben, a vajúdó biztosan tudhatja, hogy önmaga lehet és megfeledkezhet önmagáról, mert a segító jelen van ugyan, de a háttérbe húzódva. Interjúalanyaink megfogalmazták, hogy a közös pszichés tér létrehozása, azaz a vajúdás/ szülés kísérése „nagyon komoly mentális, lelki jelenlétet” kíván a segítőtől; ugyanakkor az, hogy „egy másik emberrel van egy helyzetben”, lehetóvé teszi, hogy saját segítői identitását, önmagát is megtapasztalja benne. A vajúdás/szülés során létrejövő segító kapcsolat rejtett szövedéke ily módon közös mintázatba írja a segító és a vajúdó történeteit.

\section{A kutatás korlátai}

Az IPA elemzések kis elemszámú mintával dolgoznak, nem általános összefüggéseket, hanem az egyedi mintázatokat tárják fel. Az interjúk elemzésénél a kutatók szakirodalmi olvasottsága, szemléleti keretei tudatosan befolyásolják a kapott eredmények értelmezését. A jelen tanulmányban ismertetett interjúk egy nagyobb kutatási mintába illeszkednek, az eredmények, értelmezések és összefüggésrendszerek a teljes kutatási anyag feldolgozásával nyerik el végső mélységüket és relevanciájukat.

\section{Irodalom}

Argelander, H. (2006). Első pszichoterápiás interjú. Budapest: Springmed

Csabai M., Csörsz I., \& Szili K. (2009). A gyógyító kapcsolat élménye. Budapest: Oriold és Társai

Davis-Floyd, R. (1992). Birth as an American Rite of Passage. Oakland, CA: University of California Press

Dima, G., \& Bucuta, M.D. (2012). The experience of therapeutic change for psychologist preparing to become psychoterapist. Procedia Social and Behavioral Science, 33, 672-676.

Fox, M.F., \& Hesse-Biber, S.N. (1984). Women at work. Mountain View, CA: Mayfield Publishing Company

Fülöp, E. (2013). Másodlagos traumatizáció és kiégés összefüggései az érzelemszabályozási folyamatokkal. In M. Csabai, \& J.N. Pintér (Szerk.), Pszichológia a gyógyításban. Fenomenológiai, müvészetpszichológiai és testkép-központú megközelítések (167-190). Budapest: Oriold és Társai

Héjja-Nagy, K. (2014). A szülésélmény vizsgálata a beavatkozások összefüggésében. Szakdolgozat. Perinatális Szaktanácsadó szakirányú továbbképzés. Budapest: ELTE Pedagógiai és Pszichológiai Kar

Hunter, B. (2001). Emotion work in midwifery: a review of current knowledge. Journal of Advanced Nursing, 34(4), 436-444.

Hunter, B., Berg, M., Lundgren, I., Ólafsdóttir, A., \& Kirkham, M. (2008). Relationships: The hidden threads in the tapestry of maternity care. Midwifery, 24, 132-137. 
Judge, T.A., \& Livingston, B.A. (2008). Is the gap more than gender? A longitudinal analysis of gender, gender role orientation, and earnings. Journal of Applied Psychology, 93, 9941012.

Keating, A., \& Fleming, V. (2009). Midwives' experiences of facilitating normal birth in an obstetric-led unit: a feminist perspective. Midwifery, 25, 518-527.

Kisdi, B. (Szerk.) (2015). Létkérdések a születés körül. Budapest: L'Harmattan

Kisdi, B. (2012). A női test dekolonizációja. A szülés posztmodern szemlélete. Néprajzi Látóhatár, 2012/3, 23-44.

Kitzinger, S. (2008). A szülés árnyékában. Katarzis vagy krízis? Budapest: Alternatal

Kovács, M. (2006). A kiégés jelensége a kutatási eredmények tükrében. Lege Artis Medicinae, 16(11), 981-987.

Larkin, P., Begley, C.M., \& Devane D. (2009). Women's experiences of labour and birth: an evolutionary concept analysis. Midwifery, 25(2), 49-59.

Larsson, Ch., Saltvedt, S., Edman, G., Wiklund, I., \& Andolf, E. (2011). Factors independently related to a negative birth experience in first time mothers. Sexual and Reproductive Healthcare, 2, 83-89.

Leinweber, H.J., \& Rowe, J. (2010). The costs of 'being with the woman': secondary traumatic stress in midwifery. Midwifery, 26(1), 76-87.

Lipták, J. (2017). Együttérző gyógyitás. Interjú dr. Robin Youngsonnal, a Szívvel az egészségügyben mozgalom alapítójával. Letöltve: 2017.11. 01-jén: http:/ / medicalonline.hu/gyogyitas/ cikk/egyutterzo_gyogyitas

Lundgren, I., \& Dahlberg, K. (2002). Midwives' experience of the encounter with women and their pain during childbirth. Midwifery, 18, 155-164.

Lundgren, I., Karlsdottir, S.I., \& Bondas, T. (2009). Long term memories and experiences of childbirth in a Nordic context - a secondary analysis. International Journal of Qualitative Studies on Health and Well-being, 4(2), 115-128.

Novák, J. (2015). Normális szülés Magyarországon a 20. század elejétől napjainkig. In B. Kisdi (Szerk.), Létkérdések a születés körül (149-183). Budapest: L'Harmattan

Osborn, M., \& Smith, J.A. (1998). A personal experience of chronic being lower back pain: An interpretative phenomenological analysis. British Journal of Health Psychology, 3, 65-83.

Pápay, N., \& Rigó, A. (2015). Bevezető. In Pápay N. \& Rigó A. (Szerk.). Reproduktív egészségpszichológia (353-370). Budapest: ELTE Eötvös Kiadó

Pikó, B. (2005). Lelki egészség a modern társadalomban. Budapest: Akadémiai Kiadó

Rácz, J., Kassai, Sz., \& Pintér, J.N. (2015). Az interpretatív fenomenológiai analízis (IPA) mint kvalitatív pszichológiai eszköz bemutatása. Szakirodalmi összefoglalás. Magyar Pszichológiai Szemle, 71(2), 313-336.

Rácz, J., Kassai, Sz., \& Pintér, J.N. (2016). Az interpretatív fenomenológiai analízis (IPA) elmélete, módszertana és alkalmazási területei. Budapest: L'Harmattan

Romano, A.M., \& Lothian, J.A. (2008). Promoting, protecting and supporting normal birth: a look at the evidence. Journal of Obstetric, Gynecologic and Neonatal Nursing, 37(1), 94-105.

Smith, J.A., Flowers, P., \& Larkin, M. (2009). Interpretative phenomenological analysis: Theory, method and research. London: Sage

Soltész, A., Rigó, A., \& Pápay, N. (2015). Az együttszülés jelentősége. In N. Pápay, \& A. Rigó (Szerk.), Reproduktív egészségpszichológia (353-370). Budapest: ELTE Eötvös Kiadó

Székely, Zs., \& Csabai, M. (2017). Együtt szülés. A szülés során létrejövő segítő kapcsolat kvalitatív vizsgálata a társadalmi nemek és a hatalom szempontjából. Társadalmi Nemek Tudománya Interdiszciplináris eFolyóirat. Letöltve: 2018. január 31-én: http:/ / tntefjournal. $\mathrm{hu} /$ vol7/iss2/szekely_csabai.pdf 
Székely, Zs. (2016). „Ilyenkor szoktam remegni...” - rendhagyó esettanulmány egy kutatási interjú alapján. Lélekelemzés, 11(1), 79-91.

Szokolszky, Á. (2004). Kutatómunka a pszichológiában. Budapest: Osiris Kiadó

Taylor, S.E., Klein, L.C., Lewis, B.P., Gruenewald, T.L., Gurung, R., \& Updegraff, J. (2000). Female responses to stress: Tend-and-befriend, not fight-or-flight. Psychological Review, 107(3), 411-429.

Uvnäs-Moberg, K., \& Petersson, M. (2004). Oxytocin: Biochemical link for human relations. Mediator of antistress, well-being, social interaction, growth, healing. Läkartidningen, 101(35), 2634-2639.

Vajda, J. (2006). A terápiás hatás, mint melléktermék. Thalassa, 17(1), 123-136.

Varga, K. (2009). Szexualitás, szülés, kötődés: az oxitocin pszichoemotív hatásai. In E. Bagdy, Zs. Demetrovics, \& J. Pilling (Szerk.), Polihistória. Köszöntők és tanulmányok Buda Béla 70. születésnapja alkalmából (447-474). Budapest: Akadémiai Kiadó

Varga, K. (2015). A szülés élménye. Út a „jó minőségü" szüléshez, születéshez. In N. Pápay \& A. Rigó (Szerk.), Reproduktív egészségpszichológia (67-86). Budapest: ELTE Eötvös Kiadó

Varga, K., Andrek, A., \& Herczog, M. (2011). A várandósság és a szülés pszichológiai vonatkozásai és társadalmi beágyazottsága. In I. Danis, M. Farkas, M. Herczog, \& L. Szilvási (Szerk.), A génektől a társadalomig: a koragyermekkori fejlődés szinterei. Biztos Kezdet Kötetek 1 (230-281). Budapest: Nemzeti Család- és Szociálpolitikai Intézet

Varga, K., \& Suhai-Hodász, G. (2010). Szülés és születés. Lélektanon innen és túl. Budapest: Pólya

Varró, G. (2015). Így szülünk mi - szülési lehetőségek és gyakorlat Magyarországon. In B. Kisdi (Szerk.), Létkérdések a születés körül (185-204). Budapest: L'Harmattan

Winnicott, D.W. (2004). Az egyedüllét képessége. In B. Péley (Szerk.), A kapcsolatban bontakozó lélek. Válogatott tanulmányok (114-119). Budapest: Új Mandátum

\section{Szerzói munkamegosztás}

Székely Zsófia: adatgyújtés és elemzés, kutatás tervezése, eredmények értelmezése, kézirat megszövegezése, szakirodalmi hivatkozások

Csabai Márta: kutatás tervezése, eredmények értelmezése, kézirat megszövegezése

\section{Nyilatkozat érdekütközésról}

A szerzók kijelentik, hogy esetükben nem állnak fenn érdekütközések. 


\title{
Midwives' experiences of the helping relationship: an interpretative phenomenological analysis
}

\author{
SZÉKELY, ZSÓFIA - CSABAI, MÁRTA
}

Background: Scientific studies about birth and labour are often conducted in a traditional biomedical paradigm, and their results and conclusions are reflecting this approach, too. Holistic approaches of studying birth is spreading recently, and this qualitative research is falling into line with this paradigm. In most cases, birth takes place in the impersonal context of hospitals, where medicalization and technocratic environment is dominant. These circumstances are inevitable consequencies of the evolution of medical technologies, and have negative impact both on women in labor and on professionals. Professionals face serious challenges in providing humanized care, and woman-centered, personalized caregiving usually obstacled by the midwives' hierarchical-dependent positions as well. Aim: The objective of the study was to explore the experiences of midwives in their helping relationships. How the midwives experience their relationship with women? How can psychodynamic theories of helping relationships explain these phenomena? How gendered characteristics appear in the context of professional care? Method: Qualitative study using a phenomenological framework: interpretative phenomenological analysis (IPA). Setting: in-depth semistructured interviews, supplemented with thematic pictures. Participants were asked to talk about a freely chosen birth story from their practice, and additional questions were exposed. Participants: 5 hospital midwives, 5 homebirth midwives, 4 doulas (14 persons). In this paper we are discussing interviews with 4 hospital midwives. Results: Emerging themes in relation to the participants' experience of the helping relationship: personal and professional self-knowledge; learning from birthing women; mothering, emotional and physical care; conflicts with colleagues working with different professional approach. Emerging themes were grouped into Main themes: the development of the participants' professional identity; closely connected to the quality of the relationship with the birthing woman. Conclusions: Professional identity and high-functioning relationship with birthing women are interconnected issues, with significant impact on each other. It is like a 'common road' on which all participants move along. Our findings suggest that medicalization and impersonal hospital environment rarely enhance high quality professional care, including personal and emotional care. Participants of this study are seeking for occasional solutions for their polarized conflicts. Consideration should be given to vocational directions and social support.

Keywords: IPA - interpretative phenomenological analysis, childbirth, helping relationship, medicalization, humanized practice, professional identity 